\title{
Ventricular arrhythmias during treatment with alteplase (recombinant tissue plasminogen activator) in suspected acute myocardial infarction
}

\author{
R G Wilcox, Janet Eastgate, Elizabeth Harrison, A M Skene
}

\begin{abstract}
Continuous electrocardiography during the first 24 hours of a stay in a coronary care unit was used to record ventricular arrhythmias during treatment with alteplase (recombinant tissue plasminogen activator) or placebo. Recordings were made on 378 of the 436 patients admitted to a double blind trial of alteplase or placebo in one participating centre of the Anglo-Scandinavian study of early thrombosis (ASSET), patients being selected according to the availability of recorders. Of these, 309 (158 given alteplase and 151 placebo) had $>5$ hours of analysable data. Most of the arrhythmias were recorded in patients with an in hospital diagnosis of myocardial infarction. Ventricular couplets and venricular tachycardia were significantly more common in the patients treated with alteplase. Further, in patients with myocardial infarction who had ventricular extrasystoles, couplets, or ventricular tachycardia type a, the number of hours in which each arrhythmia was recorded was significantly higher in the alteplase group. The various ventricular arrhythmias in the alteplase group tended to cluster in the first 4-12 hours of the recordings. During the first 24 hours admission there were four episodes of ventricular fibrillation in the alteplase group and five in the placebo group of taped patients. By one month there had been 18 deaths in these 309 patients (alteplase four, placebo 14). These bore no relation to any recorded arrhythmia. Clinical records for the patients with no or minimal tape data yielded six further episodes of ventricular fibrillation during the first 24 hours (three in the alteplase group and three in the placebo group). Of the total 436 patients, 10 of the 218 patients in the alteplase group had died by one month compared with 22 of the 218 patients treated with placebo.
\end{abstract}

The use of alteplase increases the incidence of non-life threatening ventricular arrhythmias. These results, however, suggest that arrhythmia after thrombolysis in the pre-hospital phase may be less of a problem than it is per-
Coronary thrombolysis is now an accepted treatment for eligible patients who present within 6 hours of onset of symptoms of acute myocardial infarction and the risk-benefit ratio of such treatment is gradually emerging from several large clinical trials. ${ }^{1-4}$ One particular concern, especially in the pre-hospital setting, is the likelihood of such treatment provoking serious ventricular arrhythmias. In animal studies, for instance, both the occlusion of a coronary artery and its reperfusion are usually accompanied by a burst of ventricular extrasystoles that occasionally degenerates into ventricular fibrillation..$^{5-7}$ Incomplete reperfusion seems to be particularly provocative. ${ }^{8}$

In humans ventricular extrasystoles coincided with angiographically proven coronary artery reperfusion,' but in none of the large clinical trials does there seem to be an increase in serious ventricular arrhythmias during hospital stay. The data available during the operative hours of thrombolysis (and presumed reperfusion) are less complete with most of the human data coming from studies that used intracoronary or intravenous streptokinase as the thrombolytic agent. Although ventricular extrasystoles are common and cannot be prevented by lignocaine, serious events are not. ${ }^{10} 11$ In the placebo controlled intravenous streptokinase in acute myocardial infarction (ISAM) and Gruppo Italiano per lo Studio della streptochinasi nell 'infarto miocardico (GISSI-1) trials, observation periods of cardiac rhythm were limited and in neither study did serious ventricular events seem to be more common in the actively treated groups. ${ }^{12}$

The extent to which alteplase (recombinant tissue plasminogen activator) is associated with ventricular arrhythmias is less clear. During the Anglo-Scandinavian study of early thrombosis (ASSET), ${ }^{4}$ a large double blind placebo controlled study that used intravenous alteplase as the thrombolytic drug, we monitored ventricular extrasystoles in 378 patients by 24 hour continuous electrocardiographic recordings, started at admission to the coronary care unit. This paper reports the findings of that study.

Patients and methods

The protocol, methods, and principal results of ASSET have already been published. ${ }^{4}$ ceived to be.

Department of
Medicine, University
Hospital, Nottingham
R G Wilcox
J Eastgate
British Heart
Foundation
Cardiovascular
Statistics Group,
University of
Nottingham
E Harrison
A M Skene
Correspondence to
Dr R G Wilcox, Department
of Medicine, University
Hospital, Nottingham
NG7 2UH
Accepted for publication
26 July 1990


Briefly, patients of either sex, aged 18-75 years inclusive, admitted to the coronary care units within 5 hours of symptoms of acute myocardial infarction were screened for eligibility and then randomised to receive either intravenous alteplase $(100 \mathrm{mg}$ over 3 hours) or placebo. Both groups also received an initial intravenous bolus of heparin 5000 units followed by an intravenous infusion of 1000 units per hour starting after completion of the trial infusion and continuing for the remainder of the patients' first 24 hours stay in the coronary care unit. During this time no other routine or prophylactic treatments were given and it was not the policy to prescribe antiarrhythmic medication for episodes of symptomless ventricular extrasystoles.

All patients in ASSET admitted to the University Hospital, Nottingham, had continuous bedside and central console single channel electrocardiographic monitoring (Simonsen and Weel 8000 series) for the duration of their stay in the coronary care unit. In addition, a continuous recording was made during the first 24 hours on to Oxford Medilog 1 tapes from the central console via a voltage attenuator, beginning as soon as possible after clinical evaluation and randomisation. A recording was attempted whenever a tape recorder was available. Data were obtained for 378 patients from 436 study admissions.

The 24 hour tapes were then analysed by an experienced technician who inspected the scan replays from an Oxford Medilog 1 tape analyser. Any equivocal episodes were re-read by one of us (RGW). We recorded the hourly incidence of the following rhythms: ventricular extrasystoles (VEs), fast and slow ventricular couplets and ventricular tachycardias, atrial fibrillation/flutter, and supraventricular tachycardia. Any episode of ventricular fibrillation, complete heart block, or asystole was also noted. Ventricular couplets and tachycardias were coded according to the description of Campbell and colleagues: ${ }^{13}$

Fast ventricular couplets Two consecutive ventricular extrasystoles with $R R$ interval $<500 \mathrm{~ms}$.

Slow ventricular couplets As above but with $\mathrm{RR}$ interval $\geqslant 500 \mathrm{~ms}$.

Ventricular tachycardia (a) Three or more consecutive ventricular extrasystoles with two successive cycles contained within $1000 \mathrm{~ms}$; (b) as above but at least one cycle of $\leqslant 500 \mathrm{~ms}$; (c) as above but with no cycle shorter than or equal to $500 \mathrm{~ms}$ (VTa, VTb, VTc).

Details of all relevant clinical events and treatments during the hospital stay and up to one month were noted as part of ASSET.

Two questions were investigated for each rhythm disturbance in turn: first, was there a difference between the treatments in terms of the number of patients showing the rhythm disturbance at any time during the course of the monitoring period? Secondly, among patients who had shown the arrhythmia was the frequency of its occurrence associated with treatment? This second issue was investigated in three ways. For each patient and arrhythmia we counted the number of hourly intervals in which the arrhythmia appeared (hours seen), the total number of instances of the arrhythmia over the taping period (total on tape), and the number of instances of the arrhythmia during the hour it was most prevalent (maximum frequency per hour).

Full 24 hour records were not available for all the taped patients because of administrative or technical difficulties which often resulted in all or large parts of the tape being unreadable. We elected to include in the statistical analysis only those tapes with $\geqslant 5$ hours worth of recorded data, there being no indication that any imbalance was induced between the treatment groups by this selection. However, instances of ventricular fibrillation, diagnostic categorisation in hospital, and one month outcome are known for all study admissions, including both untaped patients and those patients in whom taping was unsuccessful.

\section{STATISTICAL ANALYSIS}

We used standard methods for the analysis of frequency data. Distributions of total tape frequencies and maximum frequency per hour were often highly positively skewed with the occasional patient yielding values that were one or two orders of magnitude greater than all other cases in the group. Thus for treatment comparisons we used either rank sum statistics or we examined tables of grouped data. For the tables of grouped data the generalised logistic regression models described by $\mathrm{McCullagh},{ }^{14}$ were often appropriate. Medians are cited as a measure of central tendency. Distributions of the number of hours in which a particular arrhythmia was seen were more symmetrical and thus means are given for these distributions where appropriate.

Because all patients in this study were also included in the analysis of ASSET the analysis by allocated treatment group was only carried out once the ASSET database was complete and treatment codes had been released.

\section{Results}

PATIENTS

During the course of ASSET 436 patients admitted to the University Hospital, Nottingham were randomised to treatment. Tape recorders were available for $378(82 \%)$ patients. Of these recordings 309 had $\geqslant 5$ hours of analysable data (mean 21.7 hours), 11 contained some data, but were short either because of technical difficulties or early death, and 58 tapes contained no usable data because of technical problems. A total of 158 of the 309 fully analysable taped patients were treated with alteplase. The rest (151) received placebo. Nearly all $(98 \%)$ of patients in both groups received the complete dose of trial material. The treatment groups were well matched for pre-admission demographic details and clinical details on admission (table 1), time from onset of symptoms to start of trial infusion and tape length (table 2), and for in hospital diagnostic 
Table 1 Comparability of treatment groups on admission

\begin{tabular}{|c|c|c|c|c|}
\hline & \multicolumn{2}{|l|}{ All cases } & \multicolumn{2}{|c|}{ Confirmed $M I$} \\
\hline & Alteplase & Placebo & Alteplase & Placebo \\
\hline $\begin{array}{l}\text { Time (h) from onset of sym } \\
<2 \\
2-3 \\
3-4 \\
>4\end{array}$ & $\begin{array}{l}\text { start of inf } \\
9 \\
35 \\
48 \\
66\end{array}$ & $\begin{array}{r}9 \\
39 \\
45 \\
58\end{array}$ & $\begin{array}{r}8 \\
26 \\
36 \\
38\end{array}$ & $\begin{array}{r}6 \\
34 \\
31 \\
41\end{array}$ \\
\hline $\begin{array}{l}\text { Total } \\
\text { Male/female }\end{array}$ & $\begin{array}{l}158 \\
129 / 29\end{array}$ & $\begin{array}{l}151 \\
118 / 33\end{array}$ & $\begin{array}{l}108 \\
91 / 17\end{array}$ & $\begin{array}{l}112 \\
88 / 24\end{array}$ \\
\hline $\begin{array}{l}\text { Age: } \\
\quad \leqslant 45 \\
46-55 \\
56-65 \\
66-75\end{array}$ & $\begin{array}{l}16 \\
44 \\
63 \\
35\end{array}$ & $\begin{array}{l}15 \\
36 \\
56 \\
44\end{array}$ & $\begin{array}{r}9 \\
29 \\
46 \\
24\end{array}$ & $\begin{array}{l}12 \\
18 \\
47 \\
35\end{array}$ \\
\hline $\begin{array}{l}\text { Previous infarct } \\
\text { Angina } \\
\text { Hypertension } \\
\text { Diabetes }\end{array}$ & $\begin{array}{r}36 \\
70 \\
28 \\
5\end{array}$ & $\begin{array}{r}41 \\
53 \\
30 \\
6\end{array}$ & $\begin{array}{r}20 \\
42 \\
18 \\
5\end{array}$ & $\begin{array}{r}28 \\
35 \\
23 \\
4\end{array}$ \\
\hline $\begin{array}{l}\text { Smoker: } \\
\text { No } \\
\text { Ex } \\
\text { Yes }\end{array}$ & $\begin{array}{l}41 \\
38 \\
79\end{array}$ & $\begin{array}{l}38 \\
41 \\
72\end{array}$ & $\begin{array}{l}32 \\
26 \\
50\end{array}$ & $\begin{array}{l}27 \\
32 \\
53\end{array}$ \\
\hline $\begin{array}{l}\text { ECG: } \\
\text { Normal } \\
\text { Consistent with new MI } \\
\text { Other abnormal } \\
\text { Missing }\end{array}$ & $\begin{array}{r}36 \\
71 \\
51 \\
0\end{array}$ & $\begin{array}{r}27 \\
81 \\
42 \\
1\end{array}$ & $\begin{array}{r}9 \\
64 \\
33 \\
0\end{array}$ & $\begin{array}{r}8 \\
79 \\
24 \\
1\end{array}$ \\
\hline $\begin{array}{l}\text { Treatment with frusemide: } \\
\text { None } \\
40 \mathrm{mg} \\
80 \mathrm{mg} \\
\text { + vasodilator }\end{array}$ & $\begin{array}{r}116 \\
30 \\
11 \\
1\end{array}$ & $\begin{array}{r}114 \\
22 \\
14 \\
1\end{array}$ & $\begin{array}{r}74 \\
24 \\
9 \\
1\end{array}$ & $\begin{array}{r}80 \\
19 \\
12 \\
1\end{array}$ \\
\hline $\begin{array}{l}\text { Other treatment at entry } \\
\beta \text { blocker }\end{array}$ & 33 & 24 & 16 & 18 \\
\hline
\end{tabular}

ECG, electrocardiograph; MI, myocardial infarction.

Table 2 Comparability of treatment groups: time intervals

\begin{tabular}{|c|c|c|c|c|}
\hline & \multicolumn{2}{|l|}{ All cases } & \multicolumn{2}{|l|}{ Confirmed $M I$} \\
\hline & Alteplase (n) & Placebo (n) & Alteplase (n) & Placebo (n) \\
\hline $\begin{array}{c}\text { Time from in } \\
\pm 30 \mathrm{~min} \\
30-90 \mathrm{~min} \\
>90 \mathrm{~min} \\
\text { Not known }\end{array}$ & $\begin{array}{r}\text { pe: } \\
110 \\
17 \\
14 \\
17\end{array}$ & $\begin{array}{r}104 \\
12 \\
13 \\
22\end{array}$ & $\begin{array}{l}73 \\
11 \\
13 \\
11\end{array}$ & $\begin{array}{r}78 \\
11 \\
9 \\
14\end{array}$ \\
\hline $\begin{array}{l}\text { Tape hours a } \\
6-12 \\
13-18 \\
19-23 \\
24\end{array}$ & $\begin{array}{r}6 \\
21 \\
38 \\
93\end{array}$ & $\begin{array}{r}9 \\
18 \\
28 \\
96\end{array}$ & $\begin{array}{r}0 \\
11 \\
23 \\
74\end{array}$ & $\begin{array}{r}7 \\
8 \\
19 \\
78\end{array}$ \\
\hline
\end{tabular}

MI, myocardial infarction.

Table 3 Hospital diagnosis, 24 hour incidence of ventricular fibrillation and one month outcome in all 436 patients

\begin{tabular}{|c|c|c|c|c|c|c|}
\hline & \multicolumn{4}{|c|}{ Tape available (320) } & \multicolumn{2}{|c|}{ No tape data ${ }^{\star}$ (116) } \\
\hline & \multicolumn{2}{|l|}{$>5 h \dagger$} & \multicolumn{2}{|l|}{$<5 h$} & \multirow[b]{2}{*}{ Alteplase } & \multirow[b]{2}{*}{ Placebo } \\
\hline & Alteplase & Placebo & Alteplase & Placebo & & \\
\hline $\begin{array}{l}\text { Total } \\
\text { Dead at } 1 \text { month } \\
\text { Hospital diaonosis: }\end{array}$ & $\begin{array}{r}158 \\
4\end{array}$ & $\begin{array}{r}151 \\
14\end{array}$ & $\begin{array}{l}7 \\
1\end{array}$ & $\begin{array}{l}4 \\
2\end{array}$ & $\begin{array}{r}53 \\
5\end{array}$ & $\begin{array}{r}63 \\
6\end{array}$ \\
\hline $\begin{array}{l}\text { MI (dead I month) } \\
\text { IHD } \\
\text { Others } \\
V F \leqslant 24 \mathrm{~h}\end{array}$ & $\begin{array}{l}110(4) \\
25 \\
23 \\
4\end{array}$ & $\begin{array}{r}112(14) \\
21 \\
18 \\
5\end{array}$ & $\begin{array}{l}5(1) \\
0 \\
2 \\
0\end{array}$ & $\begin{array}{l}3(2) \\
0 \\
1 \\
0\end{array}$ & $\begin{array}{c}39(4) \\
12 \\
4(1) \\
3\end{array}$ & $\begin{array}{l}39(5) \\
12(1) \\
10 \\
3\end{array}$ \\
\hline
\end{tabular}

*Technical problems or recorder not available.

tGroup chosen for the statistical analysis of arrhythmia incidence.

IHD, ischaemic heart disease; MI, myocardial infarction; VF, ventricular fibrillation. categorisation and one month outcome (table 3). Table 3 also gives the diagnoses and one month outcome for the 11 patients with $<5$ hours analysable data and the 116 patients who had no data because of technical problems or were not taped because a machine was not available.

\section{ARRHYTHMIAS}

Most of the recorded arrhythmias occurred in patients with an in hospital diagnosis of myocardial infarction. Isolated ventricular extrasystoles were very common. They were seen in $96 \%$ of patients with myocardial infarction given alteplase or placebo, in $66 \%$ of noninfarct patients who received alteplase, and in $72 \%$ of non-infarct patients who received placebo. They occurred throughout the monitoring period for a mean of 17 hours in patients with a myocardial infarction and a mean of 10 hours in the non-infarct patients. However, more complex ventricular arrhythmia was much less common in the patients without infarcts (table 4).

When patients without infarcts were excluded, the incidence of each of fast and slow couplets, ventricular tachycardia a, b, and c, and supraventricular tachycardia was significantly higher in the alteplase group. In addition, a higher proportion of alteplase patients recorded a rate for isolated ventricular extrasystoles of $>30$ per hour for at least one hour.

Table 5 indicates that the treatment with alteplase was also associated with a small increase in the frequency of the occurrence of most of the arrhythmias considered. Among patients with myocardial infarction and VEs, couplets, VTas, or VTcs the number of hours during which each was seen was significantly higher in the alteplase group. There was no significant increase in the maximum frequencies per hour, but the increase in the number of hours during which an arrhythmia was seen caused a corresponding increase in the total on tape.

Hourly analysis of the patient incidence of the various arrhythmias showed that the increase in the alteplase group was more considerable during the first 12 hours of the recordings. Thereafter the incidence in both groups gradually declined (fig 1A-D).

During the first 24 hours of admission there were four reports of ventricular fibrillation in the alteplase group with analysable tapes and three reports in the group of 53 alteplase patients with no tape data. There were five reports of ventricular fibrillation in the placebo group with analysable tapes and three reports from the group of 63 placebo patients with no tape data. The ventricular fibrillation episodes proved fatal for two patients-one in the alteplase group and one in the placebo group (table 3).

\section{CLINICAL CORRELATIONS}

By one month there had been 18 deaths (four in the alteplase group and 14 in the placebo group) in the analysable patients; all deaths occurred in patients who had an in hospital 
Table 4 Number of patients with arrhythmias: by diagnosis and treatment

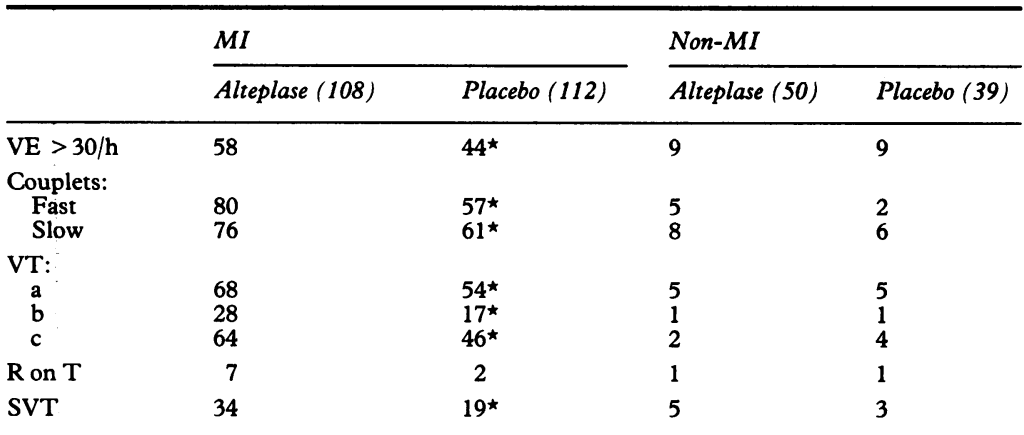

MI, myocardial infarction; SVT, supraventricular tachycardia; VE, ventricular extrasystoles, $\mathrm{VT}$, ventricular tachycardia.

*Data not consistent with the hypothesis of equal incidence rates in the two treatment groups, $(\mathrm{p}<0.05)$. Separate tests for MI and non-MI groups.

diagnosis of acute myocardial infarction. However, there seemed to be no relation between the arrhythmias recorded in the first 24 hours and the day on which death eventually occurred (table 6). Indeed, we explored the clinical database for possible differences between those patients who did or did not show ventricular arrhythmias and between those who died and those who survived; we could find no predictive features, such as age, site of infarct, or smoking habit. The excess incidence of recorded arrhythmias in the alteplase group occurred across the board, rather than being confined to a subset of patients.

\section{Discussion}

Early treatment with any of the currently available thrombolytic regimens has been shown unequivocally to save lives. ${ }^{1-4}$ However, both the GISSI 1 study and the second international study of infarct survival (ISIS 2) showed that thrombolysis was accompanied by a slight excess of deaths in the first 24-48 hours in patients treated with streptokinase. Although the cause of death is not always easy to determine, we need to confirm or refute the involvement of reperfusion arrhythmias, particularly because concern has been expressed about the safety of the environment in which thrombolysis is initiated. ${ }^{15}$

This subset of patients from ASSET now provides specific evidence that the use of alteplase is accompanied by an increased incidence of ventricular arrhythmias. Treatment with alteplase seems to increase both the number of patients who show a range of arrhythmias and to increase slightly the frequency of the occurrence of these events.

The most worrying arrhythmia, however, is ventricular fibrillation, especially if thrombolytic treatment is given before admission to hospital. In a large series from Rotterdam intracoronary streptokinase was compared with conventional treatment; a lower incidence of both early and late ventricular fibrillation was reported in the thrombolytic group. ${ }^{11}$ Similarly in the intravenous streptokinase in acute myocardial infarction (ISAM) study there was a significantly lower incidence of late, but not early, ventricular fibrillation. ${ }^{12}$ In our study the incidence of ventricular fibrillation was very low during the taping period and there was no evidence of any increase associated with alteplase. Overall, in the ASSET study the incidence of ventricular fibrillation in hospital was $3.7 \%$ in the alteplase group and $4.6 \%$ in the placebo treated patients.

It is pertinent to compare the overall pattern of arrhythmias seen in this study with similar studies of streptokinase. After analysis of one minute electrocardiograms taken every hour, Willems and colleagues reported fewer ventricular extrasystoles in the streptokinase treated group, which were attributed to the possibility of smaller infarcts than in placebo group. ${ }^{1617}$ Using intracoronary streptokinase and continuous Holter tape monitoring, Miller and colleagues concluded that both ventricular tachycardia and accelerated idioventricular rhythm were more common with active treatment but bore no relation to the degree of reperfusion achieved. ${ }^{18}$ However, in a subset of the GISSI 1 patients, only accelerated idioventricular rhythm was reported to be more common in the treatment group. ${ }^{19}$

Table 5 Frequency of arrhythmias in patients with diagnosis of myocardial infarction

\begin{tabular}{|c|c|c|c|c|c|}
\hline & & $n$ & $\begin{array}{l}\text { Mean hours } \\
\text { seen }\end{array}$ & $\begin{array}{l}\text { Median maximum } \\
\text { frequency/h }\end{array}$ & $\begin{array}{l}\text { Median total } \\
\text { on tape }\end{array}$ \\
\hline VEs & $\begin{array}{l}\text { Alteplase } \\
\text { Placebo }\end{array}$ & $\begin{array}{l}104 \\
108\end{array}$ & $\begin{array}{l}17 \cdot 8^{\star} \\
15 \cdot 3^{-}\end{array}$ & $\underline{t}$ & $\underline{t}$ \\
\hline$>30$ VEs & $\begin{array}{l}\text { Alteplase } \\
\text { Placebo }\end{array}$ & $\begin{array}{l}58 \\
44\end{array}$ & $\begin{array}{l}5 \cdot 6 \\
7 \cdot 0\end{array}$ & $\stackrel{\dagger}{-}$ & $\stackrel{\dagger}{-}$ \\
\hline Fast couplets & $\begin{array}{l}\text { Alteplase } \\
\text { Placebo }\end{array}$ & $\begin{array}{l}80 \\
57\end{array}$ & $\begin{array}{l}4 \cdot 6^{\star} \\
4 \cdot 3\end{array}$ & $\begin{array}{l}2 \\
1\end{array}$ & $\begin{array}{l}4 \\
3\end{array}$ \\
\hline Slow couplets & $\begin{array}{l}\text { Alteplase } \\
\text { Placebo }\end{array}$ & $\begin{array}{l}76 \\
61\end{array}$ & $\begin{array}{l}5 \cdot 6^{\star} \\
4 \cdot 3^{4}\end{array}$ & $\begin{array}{l}2 \\
1\end{array}$ & $3^{7^{\star}}$ \\
\hline$R$ on $T$ & $\begin{array}{l}\text { Alteplase } \\
\text { Placebo }\end{array}$ & $\begin{array}{l}7 \\
2\end{array}$ & $\begin{array}{l}1 \cdot 7 \\
1.0\end{array}$ & $\begin{array}{l}2 \\
1\end{array}$ & $\begin{array}{l}2 \\
1\end{array}$ \\
\hline VTa & $\begin{array}{l}\text { Alteplase } \\
\text { Placebo }\end{array}$ & $\begin{array}{l}68 \\
54\end{array}$ & $\begin{array}{l}4^{\cdot} 4^{\star} \\
3 \cdot 3\end{array}$ & $\begin{array}{l}2 \\
1\end{array}$ & $\begin{array}{l}4^{\star} \\
2 \cdot 5\end{array}$ \\
\hline VTb & $\begin{array}{l}\text { Alteplase } \\
\text { Placebo }\end{array}$ & $\begin{array}{l}28 \\
17\end{array}$ & $\begin{array}{l}1.9 \\
1.5\end{array}$ & $\begin{array}{l}1 \\
1\end{array}$ & $\begin{array}{l}1 \\
1\end{array}$ \\
\hline VTc & $\begin{array}{l}\text { Alteplase } \\
\text { Placebo }\end{array}$ & $\begin{array}{l}64 \\
46\end{array}$ & $\begin{array}{l}4 \cdot 5 \\
3 \cdot 3\end{array}$ & $\begin{array}{l}2 \\
2\end{array}$ & $\begin{array}{l}6 \cdot 5 \\
3\end{array}$ \\
\hline SVT & $\begin{array}{l}\text { Alteplase } \\
\text { Placebo }\end{array}$ & $\begin{array}{l}34 \\
19\end{array}$ & $\begin{array}{l}2 \cdot 1 \\
1 \cdot 8\end{array}$ & $\begin{array}{l}1 \\
1\end{array}$ & $\begin{array}{l}2 \\
2\end{array}$ \\
\hline
\end{tabular}

$\star$ Difference between treatments significant at the $5 \%$ level.

Exact number of VEs not counted for many patients but simply recorded as $>30 / \mathrm{hr}$. See footnote to table $\mathbf{4}$ for abbreviations. 


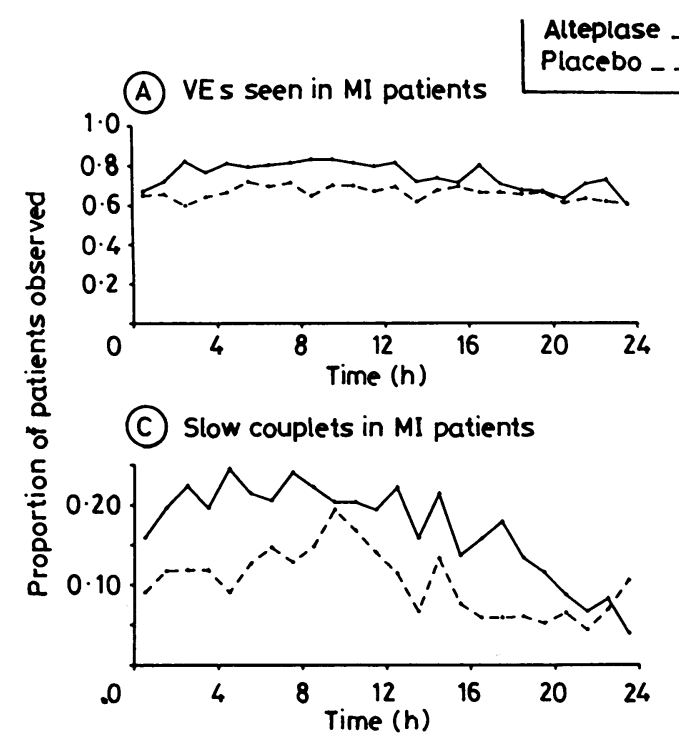

Hourly occurrence of ventricular arrhythmias.

Table 6 Days from admission to death and ventricular tachycardia during first 24 hours

\begin{tabular}{lclc}
\hline $\begin{array}{l}\text { Alteplase } \\
\text { (deaths 4) }\end{array}$ & Day & $\begin{array}{l}\text { Placebo } \\
\text { (deaths 14) }\end{array}$ & Day \\
\hline VT a & 2 & VT a, VT a/c, VT b/c & 1 \\
VT b & 4 & VT a/c, nil & 2 \\
Nil & 19 & VT a $~$ & 3 \\
Nil & 26 & VT a, nil & 6 \\
& & VT a & 7 \\
& Nil $~$ & 11 \\
& & VT a, nil & 15 \\
& & VT c & 18 \\
& & Nil & 25 \\
\hline
\end{tabular}

VT, ventricular tachycardia.

The incidence, time course, and usually benign nature of the ventricular arrhythmias appearing after thrombolysis with alteplase are very similar to that described by Cercek and colleagues in a study of 45 patients given intravenous streptokinase. ${ }^{20}$ Similarly, the pattern described in our placebo group accords with that reported by Campbell and colleagues in a small patient population. ${ }^{13}$

We therefore conclude that, in the context of a hospital coronary care unit, the use of alteplase provokes little more arrhythmias than would otherwise be seen in an individual patient and is no more likely than placebo to precipitate life threatening arrhythmias. Further, if the patient ultimately turns out not to have had an infarct we can be confident that alteplase at least has no arrhythmogenic tendencies. In these respects the findings for alteplase resemble those for streptokinase. If these favourable aspects of thrombolytic treatment obtain in the pre-hospital phase, then another obstacle to even earlier treatment would disappear. $^{21-23}$

We thank Boehringer Ingelheim UK for financial support.

1 GISSI. Effectiveness of intravenous thrombolytic treatment in acute myocardial infarction. Lancet 1986;i:397-402.

2 AIMS Trial Study Group. Effect of intravenous APSAC on mortality after acute myocardial infarction: preliminary

report of a placebo-controlled clinical trial. Lance

3 ISIS-2 Collaborative Group. Randomised trial of intravenous streptokinase, oral aspirin, both, or neither among 17,187 cases of suspected acute myocardial infarction

4 ASSET Study Group. Effects of alteplase in acute myocardial infarction: 6 month results from the ASSET Study Lancet 1990;ii:1175-8.

5 Tennant $R$, Wiggers CJ. The effect of coronary occlusion on myocardial contraction. Am J Physiol 1935;112:351-61.

6 Harris AS, Rojas AG. The initiation of ventricular fibrillation due to coronary occlusion. Exp Med Surg 1943;1 105-22.

7 Sewell WH, Koth DR, Huggins CE. Ventricular fibrillation in dogs after sudden return of flow to the coronary artery. Surgery 1955;38:1050-3.

8 Bolli R, Brandon TA, Luck JC, Miller RR, Entman ML. Deleterious effects of incomplete myocardial reperfusion on ventricular arrhythmias. J Am Coll Cardiol 1983; 1(4):1111-8.

9 Goldberg S, Greenspan AJ, Urban PL, et al. Reperfusion arrhythmia: a marker of restoration of antegrade flow arrhythmia: a marker of restoration of antegrade flow during intracoronary thrombolysis for

10 Tendera M, Campbell WB, Tennant S. Ventricular arrhythmias in patients receiving intracoronary thrombolytic treatment for acute myocardial infarction. Kardiol Pol 1986;29:673-80.

11 Vermeer F, Simoons ML, Lubsen J. Reduced frequency of ventricular fibrillation after early thrombolysis in myocardial infarction. Lancet 1986;i:397-402.

12 ISAM Study Group. A prospective trial of intravenous streptokinase in acute myocardial infarction (ISAM) mortality, morbidity, and infarct size at 21 days. $N$ Engl Med 1986;314:1465-71.

13 Campbell RWF, Murray A, Julian DG. Ventricular arrhythmias in first 12 hours of acute myocardial infarction. Natural history study. Br Heart J 1981;46:351-7.

$14 \mathrm{McCullagh}$ P. Regression models for ordinal data (with discussion). J Roy Statist Soc B for ordinal data

15 British Heart Foundation Working Group. Role of the general practitioner in managing patients with myocardial infarction: impact of thrombolytic treatment. Br Med J infarction: impact

16 Willems JL, Theiss W, Lübcke P. Arrhythmias in patients of a multicenter trial on streptokinase treatment in acute myocardial infarction. Acta Med Scand 1981;supp 648:75-84.

17 Roberts R, Husain A, Ambos HD, Oliver GC, Cox JR Jr Sobel BE. Relation between infarct size and ventricular arrhythmia. Br Heart J 1975;37:1 169-75.

18 Miller FC, Krucoff MW, Satler LF, et al Ventricular arrhythmias during reperfusion. Am Heart $J$ 1986;5: 928-32.

19 GISSI. Studio del aritmie. G Ital Cardiol 1987;17/1:73-8.

20 Cercek B, Lew AS, Laramee P, Shah PK, Peter TC, Gan $W$. Time course and characterization of ventricular arrhythmias after reperfusion in acute myocardial infarction. Am J Cardiol 1987;60:214-8.

21 Roth A, Barbash GI, Hod H, et al. Should rt-PA be administered by the Mobile Intensive Care Unit teams? Circulation 1988;78(suppl II):[Abstract 187].

22 McNeill A, Cunningham S, Flannery D, et al. Pre-admission recombinant tissue plasminogen activator. Eur Heart sion recombinant tissue plasmino

23 Castaigne AD, Herve C, Duval-Moulin A-M, et al. Prehospital use of APSAC: results of a placebo-controlled study. Am J Cardiol 1989;64:30A-3A. 